\title{
Front Matter: Volume 11095
}

, "Front Matter: Volume 11095," Proc. SPIE 11095, Women in Renewable Energy (WiRE), 1109501 (18 October 2019); doi: 10.1117/12.2551108

SPIE Event: SPIE Organic Photonics + Electronics, 2019, San Diego, California, SPIE. United States 


\section{PROCEEDINGS OF SPIE}

\section{Women in Renewable Energy (WiRE)}

Monica Lira-Cantu

Zakya H. Kafafi

Editors

12 August 2019

San Diego, California, United States

Sponsored by

SPIE

Cosponsored by

Journal of Photonics for Energy

SPIE Women in Optics

Published by

SPIE 
The papers in this volume were part of the technical conference cited on the cover and title page. Papers were selected and subject to review by the editors and conference program committee. Some conference presentations may not be available for publication. Additional papers and presentation recordings may be available online in the SPIE Digital Library at SPIEDigitalLibrary.org.

The papers reflect the work and thoughts of the authors and are published herein as submitted. The publisher is not responsible for the validity of the information or for any outcomes resulting from reliance thereon.

Please use the following format to cite material from these proceedings:

Author(s), "Title of Paper," in Women in Renewable Energy (WiRE), edited by Monica Lira-Cantu, Zakya H. Kafafi, Proceedings of SPIE Vol. 11095 (SPIE, Bellingham, WA, 2019) Seven-digit Article CID Number.

ISSN: 0277-786X

ISSN: 1996-756X (electronic)

ISBN: 9781510628830

ISBN: 9781510628847 (electronic)

Published by

SPIE

P.O. Box 10, Bellingham, Washington 98227-0010 USA

Telephone +1 3606763290 (Pacific Time) · Fax +1 3606471445

SPIE.org

Copyright (c) 2019, Society of Photo-Optical Instrumentation Engineers.

Copying of material in this book for internal or personal use, or for the internal or personal use of specific clients, beyond the fair use provisions granted by the U.S. Copyright Law is authorized by SPIE subject to payment of copying fees. The Transactional Reporting Service base fee for this volume is $\$ 21.00$ per article (or portion thereof), which should be paid directly to the Copyright Clearance Center (CCC), 222 Rosewood Drive, Danvers, MA 01923. Payment may also be made electronically through CCC Online at copyright.com. Other copying for republication, resale, advertising or promotion, or any form of systematic or multiple reproduction of any material in this book is prohibited except with permission in writing from the publisher. The CCC fee code is $0277-$ $786 \mathrm{X} / 19 / \$ 21.00$.

Printed in the United States of America by Curran Associates, Inc., under license from SPIE.

Publication of record for individual papers is online in the SPIE Digital Library.

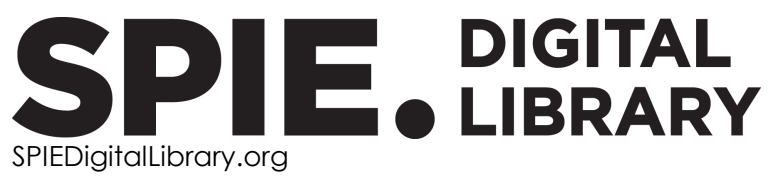

Paper Numbering: Proceedings of SPIE follow an e-First publication model. A unique citation identifier (CID) number is assigned to each article at the time of publication. Utilization of CIDs allows articles to be fully citable as soon as they are published online, and connects the same identifier to all online and print versions of the publication. SPIE uses a seven-digit CID article numbering system structured as follows:

- The first five digits correspond to the SPIE volume number.

- The last two digits indicate publication order within the volume using a Base 36 numbering system employing both numerals and letters. These two-number sets start with $00,01,02,03,04$, 05, 06, 07, 08, 09, OA, OB ... 0Z, followed by 10-1Z, 20-2Z, etc. The CID Number appears on each page of the manuscript. 


\title{
Contents
}

\author{
$\checkmark \quad$ Authors \\ vii Conference Committee
}

POSTER SESSION

11095 ON Characterization of organic and perovskite solar cells by impedance spectroscopy [1 1095-22]

Proc. of SPIE Vol. 11095 1109501-3

Downloaded From: https://www.spiedigitallibrary.org/conference-proceedings-of-spie on 26 Apr 2023 Terms of Use: https://www.spiedigitallibrary.org/terms-of-use 
Proc. of SPIE Vol. 11095 1109501-4 Downloaded From: https://www.spiedigitallibrary.org/conference-proceedings-of-spie on 26 Apr 2023
Terms of Use: https://www.spiedigitallibrary.org/terms-of-use 


\section{Authors}

Numbers in the index correspond to the last two digits of the seven-digit citation identifier (CID) article numbering system used in Proceedings of SPIE. The first five digits reflect the volume number. Base 36 numbering is employed for the last two digits and indicates the order of articles within the volume. Numbers start with 00, 01, 02, 03, 04, 05, 06, 07, 08, 09, 0A, 0B...0Z, followed by 10-12, 20-2Z, etc.

Arredondo, Belén, ON

del Pozo, Gonzalo, ON

Hernández-Balaguera, Enrique, ON

López González, María del Carmen, ON

Martín-Martín, Diego, ON

Romero, Beatriz, ON

Proc. of SPIE Vol. $110951109501-5$ 
Proc. of SPIE Vol. 11095 1109501-6 Downloaded From: https://www.spiedigitallibrary.org/conference-proceedings-of-spie on 26 Apr 2023
Terms of Use: https://www.spiedigitallibrary.org/terms-of-use 


\section{Conference Committee}

Symposium Chairs

Zakya H. Kafafi, Lehigh University (United States)

Ifor D.W. Samuel, University of St. Andrews (United Kingdom)

Conference Chairs

Monica Lira-Cantu, Institut Català de Nanociència i Nanotecnologia (ICN2) (Spain)

Zakya H. Kafafi, Lehigh University (United States)

\section{Session Chairs}

1 Progress in Halide Perovskite Solar Cells

Zakya H. Kafafi, Lehigh University (United States)

2 Solar Energy Utilization and Light Management

Monica Lira-Cantu, Institut Català de Nanociència i Nanotecnologia (ICN2) (Spain)

3 Harvesting Energy from Photovoltaics and Triboelectrics

Natalie Stingelin, Georgia Institute of Technology (United States)

4 Energy Conversion and Energy Storage

Rachel S. Goldman, University of Michigan (United States) 
Proc. of SPIE Vol. 11095 1109501-8

Downloaded From: https://www.spiedigitallibrary.org/conference-proceedings-of-spie on 26 Apr 2023 Terms of Use: https://www.spiedigitallibrary.org/terms-of-use 